FIU Law Review

\title{
What Happens in State Court Stays in State Court Comity and the Relitigation Exception to the Anti-Injunction Act
}

Juan Antonio Solis

Jones Day, j.antonio.solis95@gmail.com

Rory Ryan

Baylor Law School, rory_ryan@baylor.edu

Follow this and additional works at: https://ecollections.law.fiu.edu/lawreview

Part of the Civil Procedure Commons, Courts Commons, and the Jurisdiction Commons

Online ISSN: 2643-7759

Recommended Citation

Juan Antonio Solis \& Rory Ryan, What Happens in State Court Stays in State Court Comity and the Relitigation Exception to the Anti-Injunction Act, 15 FIU L. Rev. 175 (2021).

DOI: https://dx.doi.org/10.25148/lawrev.15.2.5

This Article is brought to you for free and open access by eCollections. It has been accepted for inclusion in FIU Law Review by an authorized editor of eCollections. For more information, please contact lisdavis@fiu.edu. 


\title{
What Happens in State Court Stays in State Court
} COMITY AND THE RELITIGATION EXCEPTION TO THE ANTI-INJUNCTION ACT

\author{
Juan Antonio Solis ${ }^{*} \&$ Rory Ryan ${ }^{* *}$
}

I. Introduction

II. Background: The Anti-Injunction Act and the Relitigation

Exception

A. The Anti-Injunction Act and Its Exceptions ........................... 179

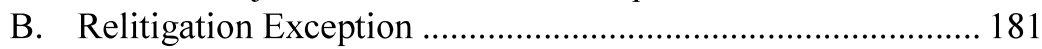

III. The Preclusive Effect of Preclusion Rulings and Parsons Steel .... 183

A. Full Faith and Credit in Related Litigation ............................. 183

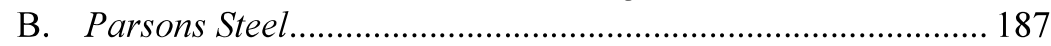

IV. Comity and Interlocutory Preclusion Denials ................................ 190

A. Injunctions, Bars, and Permissions ........................................ 191

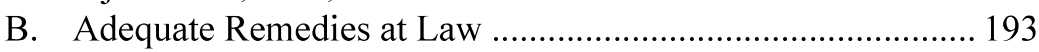

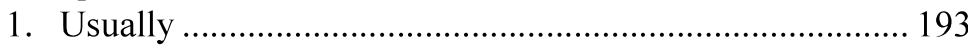

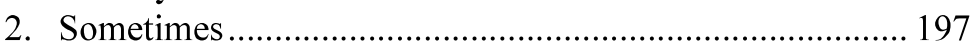

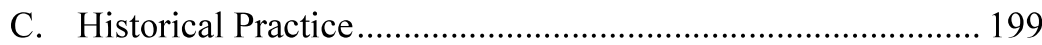

D. Beyond Preclusion: Clarity and Comity ……......................... 201

1. It's All About Preclusion?.................................................. 201

2. Gamesmanship and Purposeful Delay............................... 202

3. More than Preclusion: It Should Be Rare......................... 206

a. Express and Unambiguous Denial............................... 207

b. Balancing Comity and Relitigation .............................209

4. Practical Considerations of Comity ....................................2 211

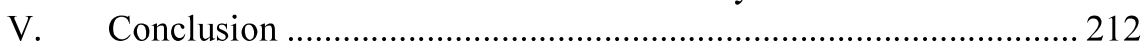

\section{INTRODUCTION}

Kid: Dad, can I go to the big party?

Dad: Did you ask mom?

\footnotetext{
* Associate, Jones Day. A special thanks to the Hon. Ignacio Torteya, III, Magistrate Judge, and Fernando S. Domene for reading earlier drafts of this Article.

** Law Professor at Baylor Law. Former Clerk to the best example of a jurist and lawyer. I thank all the students at Baylor Law who showed such energy and resiliency during these pandemic times. You inspire me.
} 
Kid: Yes. She said no.

Dad: Sure, you can go. And thanks for asking mom first. Good relationships are built on respect and comity.

Kid: What's comity?

Dad: Having due regard for another authority, you know respect and proper courtesy.

Kid: But mom said "no"?

Dad: Go read the cases about the relitigation exception to the AntiInjunction Act. Then you'll understand.

Kid: Just wait until mom finds out you're letting me go to the party.

The kid gets it. Comity is about proper respect for another authority. In the parental example, it goes without saying that comity requires far more than respecting the decision of another parent who agrees with you. Comity means respecting decisions, not just sequencing them. That sums up this article. What presents as an extraordinarily technical point of law governing parallel proceedings can actually be explained by the kid's wisdom: contradicting mom's decision is not comity.

So, let's move from parental co-authority to parallel proceedings. Forgive the long introduction, but to frame this important problem, the importance of parallel proceedings, different sovereigns, general rules of preclusion, and the Anti-Injunction Act cannot be given short shrift.

By parallel proceedings, we mean litigation between mostly the same parties over the same basic fact situation. ${ }^{1}$ Sometimes, that happens when both parties have claims and they race to be plaintiffs in the courts of the same sovereign-duplicative suits in, say, Iowa state court or in different

\footnotetext{
1 In some circumstances, "parallel proceedings" may be a term of art whose definition has significance. We need no such precision here and use the term more colloquially to mean litigation in two places over the same subject matter between or among the same parties.
} 
federal courts. In those same-sovereign situations, simple housekeeping rules permit transfer of those cases within the courts of that sovereign. ${ }^{2}$

But that housekeeping simplicity vanishes when one suit is federal and the other is state. Now, the simplicity of rules such as "first filed" yields to the practicality and intensity of one sovereign preemptively ending a lawsuit filed in another sovereign. ${ }^{3}$ To put it simply, law students, lawyers, and sometimes judges are shocked by the revelation that there is ordinarily no doctrine that prevents the sequential filing or the simultaneous litigation of factually related suits. ${ }^{4}$ It's not a race to filing. ${ }^{5}$ It's a race to judgment. ${ }^{6}$

Preemption creates the race to judgment when cases proceed in different sovereigns' courts. That is, even though no principle usually bars simultaneous litigation of related matters, once a federal or state court renders a final judgment, that judgment will operate to end factually related matters. Usually, 1L students learn in Civil Procedure, the winner takes the judgment to the remaining forum and raises preclusion as an affirmative defense to continued litigation.?

The relitigation exception to the Anti-Injunction Act creates an important procedural variant in one specific but important and recurring situation. That is, when parallel litigation:

- exists in federal and state court; and

- results in the federal court rendering a final judgment first.

When this happens, the federal judgment holder, Fred, often has two options:

- amend (or supplement) state-court pleadings and raise preclusion in state court; or

- ask the judgment-rendering federal court to issue an injunction against the state court proceeding. ${ }^{8}$

2 E.g., Manuel v. Convergys Corp., 430 F.3d 1132, 1135 (11th Cir. 2005).

3 See generally Spellman v. Express Dynamics, LLC, 150 F. Supp. 3d 378 (D.N.J. 2015).

4 Exxon Mobil Corp. v. Saudi Basic Indus. Corp., 544 U.S. 280, 294 n.9 (2005).

5 Restatement (SECOND) OF JUdGMENTS $§ 14 \mathrm{cmt}$. a (AM. LAW INST. 1982) (“[W]hen two actions are pending which are based on the same claim, or which involve the same issue, it is the final judgment first rendered in one of the actions which becomes conclusive in the other action (assuming any further prerequisites are met), regardless of which action was first brought.")

6 See Chicago, R.I. \& P. Ry. Co. v. Schendel, 270 U.S. 611, 615-17 (1926).

7 See Martin H. Redish, The Anti-Injunction Act Reconsidered, 44 U. CHI. L. REV. 717, 723 (1977). Often, the terms F1 and F2 are used in preclusion scholarship, with F1 denoting the court that renders the allegedly preclusive judgment and F2 the court in which the judgment is supposed to preclude something. For those who prefer that terminology, our ultimate focus is on the situation where: (1) F1 is the state court; (2) the party winning in F1 raises preclusion in State court as F2; (3) loses; and then (4) returns to $\mathrm{F} 1$ for a relitigation injunction.

8 See 28 U.S.C. $\$ 2283$ (2021). 
This Article explores what happens when the winner of the federal judgment wants two bites at the preclusion apple. That is, assume that Fred could choose option A or B. Can Fred do the mom-then-dad thing by trying A and then B? Stated more precisely, what if Fred plans to ask mom (the state court in A) and, if that fails, to ask dad (the federal court in option B) to overrule mom? Even if Fred prefers the federal forum, he almost surely would prefer to get two bites at the preclusion apple, which is enabled if Fred knows dad won't respect mom's ruling.

The Supreme Court seemingly created a no-two-bites principle in Parsons Steel v. First Alabama Bank thirty-five years ago. ${ }^{9}$ But that case's unusual posture left open the question we now address. Parsons Steel held that the relitigation exception does not trump the Full Faith and Credit Act. ${ }^{10}$ Said another way, Parsons Steel undoubtedly requires a federal court to honor preclusive state-court rulings. So, if a party chooses option $\mathrm{A}$ above and proceeds to final judgment in A, option B is foreclosed by the Full Faith and Credit Act.

But what if the state court denies Fred's preclusion argument firmlybut not technically rendering a final judgment under state preclusion law. There, the Full Faith and Credit Act would not, standing alone, prohibit the federal dad from overruling the state mom's denial. In our view, both precedent and good policy point towards the same answer:

Absent extraordinary circumstances, a federal court must deny a relitigation injunction if the party seeking the injunction has already presented the underlying preclusion argument to the state court and unambiguously lost.

Even if that state court ruling is not, in preclusion terms, "final," the federal court would unduly interfere with the tradition of state-federal authority. And by acting as a de facto appellate court ending state proceedings by overruling a prior ruling, the federal injunction would create the friction the Anti-Injunction Act seeks to avoid.

Although intersystem harmony is enough reason for Supreme Court review, the unequal treatment by lower courts reveals a more pressing need. Some courts generally forbid such injunctions, ${ }^{11}$ others generally permit

9 Parsons Steel, Inc. v. First Ala. Bank, 474 U.S. 518, 524 (1986).

$10 \quad$ Id. at 524-25.

11 E.g., Bryan v. BellSouth, 492 F.3d 231 (4th Cir. 2007); First Ala. Bank v. Parsons Steel, Inc., 825 F.2d 1475, 1486 (11th Cir. 1987). 
them, ${ }^{12}$ and yet others are riddled with contradictory case law within the same circuit. ${ }^{13}$

To defend our rule proposed just above, we proceed in three additional parts. Part II surveys the history and purpose of the Anti-Injunction Act and its relitigation exception. Part III describes the Parsons Steel decision and how the state court's ruling on preclusion impacts the federal court's ability to enjoin the state court. Part IV explains the right answer, defends it, and addresses counterarguments.

\section{BACKGRound: THE ANTI-INJUNCTION ACT AND THE RELITIGATION EXCEPTION}

Merely reading words on paper, it may be easy to underappreciate the magnitude of the area governed by the Anti-Injunction Act. Sure, the Supremacy Clause elevates federal law over contradictory state law..$^{14}$ But it's another step to say that federal courts-aside from the Supreme Courtcan enjoin pending cases in a sovereign state's courts. The Anti-Injunction Act, in place since around the framing, has basically prevented federal courts from enjoining state court proceedings. Part A below covers that general bar and the structure of its exceptions. Part B introduces the preclusion-based exception relevant to this Article, known as the relitigation exception.

\section{A. The Anti-Injunction Act and Its Exceptions}

Enacted in $1793,{ }^{15}$ the Anti-Injunction Act's general bar serves the revered principal of comity - or proper respect for the authority of another decisionmaker. ${ }^{16}$ In the Anti-Injunction context, comity means, of course, proper respect for the workings of state courts, sometimes referred to in a related context as "Our Federalism." ${ }^{17}$ Although the lack of a congressional

12 E.g., Ramsden v. AgriBank, FCB, 214 F.3d 865 (7th Cir. 2000); Sandpiper Village Condo v. La.-Pac. Corp., 428 F.3d 831 (9th Cir. 2005); cf. Garcia-Monagas v. De Arellano, 674 F.3d 45 (1st Cir. 2012).

13 Compare Duffy \& McGovern Accommodation Servs. v. QCI Marine Offshore, Inc., 448 F.3d 825 (5th Cir. 2006), with Tex. Emp'rs Ins. Ass'n v. Jackson, 820 F.2d 1406, 1421 (5th Cir. 1987).

14 U.S. CONST. art. VI, cl. 2.

15 Act of March 2, 1793, ch. 22, § 5, 1 Stat. 334.

16 See Hilton v. Guyot, 159 U.S. 113, 163-64 (1895) ("CComity, in the legal sense, is neither a matter of absolute obligation, on the one hand, nor of mere courtesy and good will, upon the other. But it is the recognition which one nation allows within its territory to the legislative, executive, or judicial acts of another nation, having due regard both to international duty and convenience, and to the rights of its own citizens, or of other persons who are under the protection of its laws.").

17 See Younger v. Harris, 401 U.S. 37, 43-44 (1971). 
debate record has forced historians to speculate about the comprehensive motivation behind its enactment, ${ }^{18}$ the Supreme Court has long understood the Act's purpose is to prevent "needless friction between state and federal courts." 19 Because the country's founders designed two separate legal systems - state and federal - to operate independently of one another, they were bound to lead to conflicts and strife. ${ }^{20}$ The Anti-Injunction Act cut off, from near the framing, the notion that perhaps the Supremacy Clause meant federal proceedings would be superior to parallel state ones. ${ }^{21}$

One structural point becomes a focal part later in this Article, but it's worth mentioning as a placeholder now. The Anti-Injunction Act is a bar to injunctive relief. ${ }^{22}$ It contains no authorizations. The All Writs Act and historical principles of equity authorize and shape equitable relief, and the Anti-Injunction Act simply limits that authority to prevent undue interference with state court proceedings. ${ }^{23}$ So, saying that a case meets an exception to the Anti-Injunction Act does not somehow turn the Act into the Injunction Authorizing Act. Rather, when a case fits an exception to a bar, the result is only that the particular bar doesn't apply to that case.

As enacted-and for 100 years after-the statute Congress passed expressed an absolute ban against a federal court ${ }^{24}$ enjoining pending state court proceedings. ${ }^{25}$ That is, the Act contained no exceptions. But then situations arose that convinced federal courts that they should be able to enjoin pending state court proceedings. Much like the tortured history of the supplemental-jurisdiction saga, ${ }^{26}$ courts created something extratextual, the

\footnotetext{
18 John Daniel Reaves \& David S. Golden, The Federal Anti-Injunction Statute in the Aftermath of Atlantic Coast Line Railroad, 5 GA. L. REV. 294, 294-99 (1971).

19 Okla. Packing Co. v. Okla. Gas \& Elec. Co., 309 U.S. 4, 9 (1940).

20 See Vendo Co. v. Lektro-Vend Corp., 433 U.S. 623, 630-31(1977) (plurality opinion).

21 Telford Taylor \& Everett I. Willis, The Power of Federal Courts to Enjoin Proceedings in State Courts, 42 YALE L.J. 1169, 1171 (1939); Note, Federal Power to Enjoin State Court Proceedings, 74 HARV. L. REV. 726, 727 n.11 (1961); see also Andrea R. Lucas, Balancing Comity with the Protection of Preclusion: The Scope of the Relitigation Exception to the Anti-Injunction Act, 97 VA. L. REV. 1475, 1478-79 (2011).

2228 U.S.C. $\S 2283$ (2018)

23 See, e.g., In re GMC Pick-Up Truck Fuel Tank Prods. Liab. Litig., 134 F.3d 133 (3d Cir. 1998); Negrete v. Allianz Life Ins. Co., 523 F.3d 1091 (9th Cir. 2008).

24 We use the term "federal court" because it's exact enough in nearly all cases. But if you're reading this footnote, you're probably aware that the statute actually prevents a "Court of the United States" from enjoining the pending state proceedings. Interestingly, Court of the United States is itself a statutorily defined term that includes all District Courts "of" the United States, but contains some very specific inclusions and exclusions, such as the District Court of the Canal Zone. 28 U.S.C. $\S 610$.

25 Lucas, supra note 21, at 1479.

26 See generally Supplemental Jurisdiction and Section 1367: The Case for a Sympathetic Textualism, 148 U. PENN. L. REV. 109, 109-10 n.3 (1999) (compiling early history and dialogue about Section 1367)
} 
Supreme Court later undermined the extratextual creations, ${ }^{27}$ and then Congress responded with a statute. Visually: ${ }^{28}$

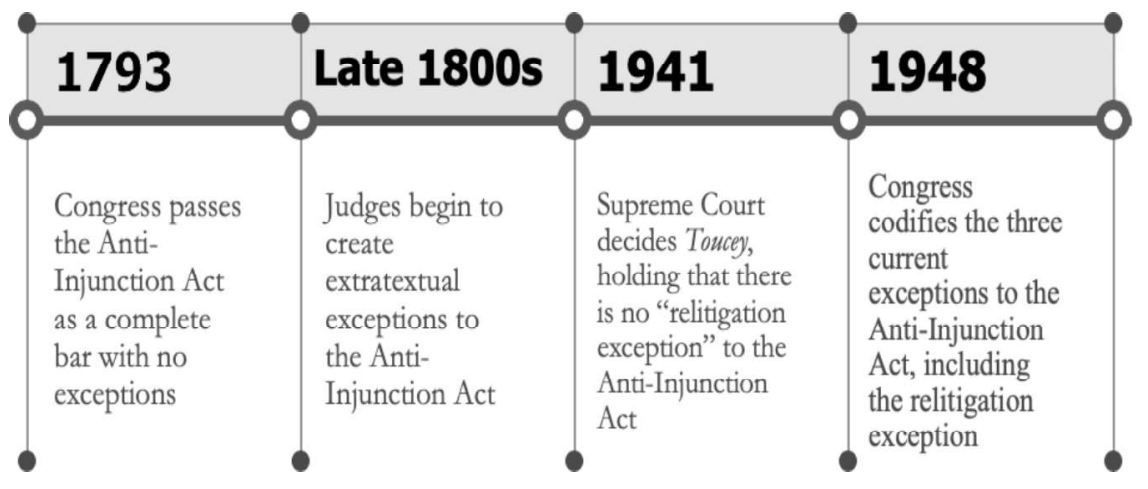

This unstable history seems to have convinced the Court to double down on its original and correct view that the Act represents a "fundamental principle of a dual system of courts" that should "not be whittled away by judicial improvisation." 29 Thus, to prevent federal courts from exerting unauthorized power over state courts, the Supreme Court explained, state court proceedings "should normally be allowed to continue unimpaired by intervention of the lower federal courts, with relief from error, if any, through the state appellate courts and ultimately [the Supreme] Court." 30 And part of the respect and comity due under the Act is a resolve-all-doubts principle. That is, when a question emerges about whether an injunction should issue, doubts should be resolved against issuing the relief. ${ }^{31}$ And importantly, the Act's exceptions-such as the relitigation exception to which we now turnmust be construed narrowly and not expanded by judicial interpretation.

\section{B. Relitigation Exception}

For civil litigation, the most important exception ${ }^{32}$ that Congress codified is known as the relitigation exception, which removes the Act's

27 See generally Toucey v. New York Life Ins. Co., 314 U.S. 118 (1941).

28 See generally id. This timeline was created by the authors of this article.

29 Vendo Co. v. Lektro-Vend Corp., 433 U.S. 623, 630-31 (1977).

30 Chick Kam Choo v. Exxon Corp., 486 U.S. 140, 146 (1988).

31 See Atl. Coast Line R.R. Co. v. Bhd. of Locomotive Eng'rs, 398 U.S. 281, 297 (1970).

32 The other two exceptions are, respectively, the expressly authorized exception and the necessary-in-aid-of-jurisdiction exception. For general guidance on the Act and these exceptions, see, for example, James E. Pfander \& Nassim Nazemi, The Anti-Injunction Act and the Problem of Federal-State 
general bar ${ }^{33}$ when the federal court is asked "to protect or effectuate its judgments." ${ }^{34}$ That is, when someone continues to litigate a matter actually resolved by the federal court, the Anti-Injunction Act's rigid bar is lifted. ${ }^{35}$

Although the relitigation exception does remove the Act's bar when needed to protect a federal judgment with a federal injunction, it hardly elevates relitigation above all federalism interests. Take the Supreme Court's opinion in Atlantic Coast Line. There, in the context of parallel federal-state litigation, a state court refused to retract an injunction obviously at odds with a recent Supreme Court precedent. ${ }^{36}$ The state-court loser then returned to federal court and sought to "protect or effectuate" the supremacy of federal law. The Supreme Court rejected the attempt and held that the relitigation exception was to be construed narrowly. ${ }^{37}$ Importantly, the Court noted, federal courts (and injunctions) are not available merely because of a perceived slight of federal law. ${ }^{38}$ Even if the state court is wrong, the AntiInjunction Act prevents constructive appeal via injunction. ${ }^{39}$

Jurisdictional Overlap, 92 TEX. L. REV. 1 (2013); Federal Court Intervention in State Proceedings, 86 HaRV. L. Rev. 207; Richard Fallon Jr., The Ideologies of Federal Courts Law, 74 VA. L. REV. 1141 (1988); Tanya Pierce, It's Not Over 'Til It's Over: Mandating Federal Pretrial Jurisdiction and Oversight in Mass Torts, 79 Mo. L. REv. 27 (2014); Andrew Weinstein, Avoiding the Race to Res Judicata: Federal Antisuit Injunctions of Competing State Actions, 75 N.Y.U.L. REv. 1085 (2000); James P. George, Parallel Litigation, 51 BAYLOR L. ReV. 769 (1999); Eric Roberson, Comity Be Damned: The Use of Antisuit Injunctions Against the Courts of a Foreign Nation, 147 U. PENN. L. REv. 409 (1998).

3328 U.S.C. \& 2283 (2018). The Anti-Injunction Act applies regardless of which suit was filed first, state or federal. However, the Act does not apply when a party seeks an anti-suit injunction, i.e., an injunction against future state court proceedings that are not yet pending. See Laker Airways v. Sabena, Belgian World Airlines, 731 F.2d 909, 915 (D.C. Cir. 1984) ("Ordinarily antisuit injunctions are not properly invoked to preempt parallel proceedings on the same in personal claim in foreign tribunals.")

34 E.g., Aptim Corp. v. McCall, 888 F.3d 129, 145 (5th Cir. 2018).

35 E.g., Jackson v. Carter Oil Co., 179 F.2d 524, 526-27 (10th Cir. 1950) (explaining the effect of the 1948 revisions on the Court's decision in Toucey). Although we (and courts) write in terms of "enjoining state-court proceedings," more commonly the injunctions are styled against one of the parties. This formality is unimportant, as the Anti-Injunction Act applies equally to injunctions against parties or lawyers proceeding in state court. Atl. Coast Line R. Co., 398 U.S. at 287.

36 Id. at 297.

$37 I d$. at 289, 293. Although both proceedings involved the same subject matter, the original federal judgment never referred to the state law's effect on the injunction, which was the contested issue at the state court. $I d$.

38 Id. at $289,293,296$. ("Any doubts as to the propriety of a federal injunction against state court proceedings should be resolved in favor of permitting the state court to proceed," and litigants required to pursue appeals through the state court system and, ultimately, certiorari from the Supreme Court).

39 See id. 
While courts disagree about several issues ${ }^{40}$ involving this exception, ${ }^{41}$ we focus on just one-the two-bites-at-the-preclusion-apple problem. To focus on that problem, let's return to the two options described in the introduction. Recall there that Fred holds a federal judgment. And, in some circumstances, Fred can choose between (A) raising preclusion in state court or (B) using the judgment's preclusive effect to justify an injunction from the federal court that rendered the judgment. Using those choices, let's assume that Fred could choose either A or B. What if Fred chooses option A, but then when that fails, chooses option B?

Stated differently, if a party is entitled to a federal audience, should the party lose that audience if the party first chooses to present the matter to the state court? As the next Part shows, there are actually two reasons for the general "no" answer: the Full Faith and Credit Act (Part III) and comity (Part IV).

\section{The Preclusive Effect of Preclusion Rulings ANd PARSONS STEEL}

There are two main takeaways from Part III. First, federal courts must, by statutory command, give Full Faith and Credit to a state-court ruling. And second, sometimes that means giving preclusive effect to how a state court resolves a preclusion issue.

\section{A. Full Faith and Credit in Related Litigation}

Although the constitutional ${ }^{42}$ and statutory ${ }^{43}$ Full Faith and Credit laws involve much more than preclusion, preclusion is the part this Article cares

40 One question continues to linger. In an early case which is cited below, Chick Kam Choo, the Supreme Court suggested that a relitigation injunction was only available to stop matters that had actually been litigated. This, of course, would mean a relitigation exception would be available when a movant sought one based on the issue-preclusive effect of a federal judgment but not if the party was only arguing about claim preclusion (or its relative via the compulsory counterclaim rules). See Chick Kam Choo v. Exxon Corp., 486 U.S. 140 (1988) (discussing scope of the relitigation exception); see also Smith v. Bayer Corp., 564 U.S. 299 (2011) (same but in the class action context); Lucas, supra note 21, at 1476.

41 See infra notes 102-103, discussing how courts disagree about whether a party seeking an injunction under the relitigation exception must satisfy the traditional equitable requirement that the movant have no adequate remedy at law.

42 U.S. CONST. art IV, $\S 1$ ("Full Faith and Credit shall be given in each State to the ... judicial proceedings of every other State.")

4328 U.S.C. $\$ 1738$ (The "judicial proceedings of [one State] . . shall have the same full faith and credit in every court within the United States . . a they have by law or usage in the courts of such State ... from which they are taken.") 
about. By statute, a federal court ${ }^{44}$ must give Full Faith and Credit to state court proceedings. Translated to preclusion, this means that federal courts are bound by state-court determinations and must give them the same preclusive effect as would another court of that state..$^{45}$ For example, when a Texas state court rules, a federal court in Texas or a state court in Delaware must consult the decisional preclusion law developed by the Texas Supreme Court and apply it. ${ }^{46}$ Of course, the corollary is that if a state-court ruling would not be preclusive under its state's laws, then the second court is not bound as a matter of Full Faith and Credit. ${ }^{47}$

Two aspects of preclusion law are sometimes confused, may vary among states, and become relevant to our conclusion. First, issue preclusion does not require a judgment on the merits. ${ }^{48}$ Although claim preclusion does require a valid final judgment on the merits, issue preclusion does not, which explains why dismissals for lack of jurisdiction or venue still bind the parties as to issues actually litigated and essential to the final judgment (or dismissal). ${ }^{49}$

Second, though both claim and issue preclusion require "finality," rulings can be issue preclusive even if they do not otherwise dispose of all claims against all parties. ${ }^{50}$ In other words, finality (like jurisdiction) ${ }^{51}$ is a

44 Note the peculiar phrasing within the Full Faith and Credit Statute: "Court within the United States." At note 24, supra, we discuss the term "Court of the United States." This, of course, means a federal court. But Court within the United States is deliberately broader-meaning any court geographically located within the United States_-meaning a federal or a state court.

45 See Parsons Steel, Inc. v. First Ala. Bank, 474 U.S. 518, 525 (1986); Marrese v. Am. Acad. of Orthopedic Surgeons, 470 U.S. 373, 381 (1985).

46 See Parsons Steel, 474 U.S. at 524-25.

47 Matter of Brady, Texas, Mun. Gas Corp., 936 F.2d 212, 219 (5th Cir. 1991) ("A state court's determination that a second action was barred by the doctrine of claim preclusion [arising from bankruptcy proceedings] will bar a third identical action in the federal court. Even if that determination was erroneous, this court, and the appellants, are bound by it."); see also Garcia-Monagas v. De Arellano, 674 F.3d 45, 52 (1st Cir. 2012) ("The Commonwealth [of Puerto Rico] courts' res judicata determination itself creates a preclusive effect.").

48 Park Lake Res. Ltd v. U.S. Dep't of Agric., 378 F.3d 1132, 1136 (10th Cir. 2004) (citing Am. Surety Co. v. Baldwin, 287 U.S. 156 (1932)); cf. Taylor v. Sturgell, 553 U.S. 880, 892 (2008).

49 See Baldwin, 287 U.S. at 166-67; RESTATEMENT(SECOND) OF JUDGMENTS $§ 12$ cmt. c (AM. LAW INST. 1982)

50 Metromedia Co. v. Fugazy, 983 F.2d 350, 366 (2d Cir. 1992) ("[T]he concept of finality for collateral estoppel purposes 'includes many dispositions which, though not final in that [end of litigation] sense, have nevertheless been fully litigated."'); Twin City Pipe Trades v. Wenner Quality Servs., Inc., 869 F.3d 672, 677 (8th Cir. 2017) (listing unavailability of appellate review as merely one factor to consider in determining the applicability of issue preclusion); Bell v.Taylor, 827 F.3d 699, 707-08 (7th Cir. 2016); Fugazy, 983 F.2d at 366 (citing Lummus Co. v. Commonwealth Oil Ref. Co., 297 F.2d 80, 89 (2d Cir. 1961)) (internal quotations omitted).

51 Arbaugh v. Y \& H Corp., 546 U.S. 500, 511-512 (2006). 
word of many meanings. ${ }^{52}$ While a judgment must usually dispose of all parties and claims to be "final" for appeal, ${ }^{53}$ different policies surround issue preclusion, and so the finality inquiry can, and should, make preclusive certain definitive rulings even though they are "interlocutory." 54 When a state court finds a federal judgment not preclusive and therefore refuses to dismiss a case, there's no doubt that refusal and denied dismissal lack "finality" for appeal and claim preclusion. But it's quite possible that such a denial would be considered firm enough to warrant giving it issue preclusive effect.

At long last, we see how these preclusion concepts combine with the Full Faith and Credit Clause. Let's return to Fred and recall that Fred had a federal judgment and two options for using that judgment to end state proceedings:

a) argue preclusion in state court; or

b) return to the federal court that rendered the judgment and seek an injunction under the relitigation exception.

Fred chooses A and moves for summary judgment based on his preclusion defense in Oklahoma state court. Fred loses that preclusion argument in Oklahoma state court ${ }^{55}$ and returns to federal court to obtain an injunction.

To determine whether the Oklahoma denial impacts Fred's injunction, we must start by distinguishing two scenarios.

First, take the easy situation: Assume that under Oklahoma state law, the Oklahoma court would treat the preclusion ruling as final. Although this variation is unusual, it can happen if, after the interlocutory preclusion denial, the state court enters final judgment before the party returns to federal court for a relitigation injunction. ${ }^{56}$

52 RESTATEMENT (SECOND) OF JUdGMENTS $\S \S 13,27 \mathrm{cmt}$ k (AM. LAW INST. 1982) (“'P] articular reference is made to the distinction in [Section] 13 between finality for purposes of merger and bar and finality for purposes of issue preclusion. Pursuant to this distinction, a litigation may have reached a stage at which issue preclusion is appropriate even though claim preclusion-application of the rules of merger and bar-is not.")

53 But see Ashcroft v. Iqbal, 556 U.S. 662, 671 (2009) ("Under the collateral-order doctrine, a limited set of district-court orders are reviewable 'though short of final judgment."') (internal citations omitted).

54 Fugazy, 983 F.2d at 366 (citing Lummus Co., 297 F.2d at 89) (whether a ruling that is not yet appealable may nonetheless be "final" to trigger issue preclusion depends on "the nature of the decision . the adequacy of the hearing, and the opportunity for review.")

55 If he wins, the state court suit is over, Fred won in federal court, and his opponent would have no hope in either. See Matter of Brady, Texas, Mun. Gas Corp., 936 F.2d 212, 219 (5th Cir. 1991) ("A state court's determination that a second action was barred by the doctrine of claim preclusion [arising from bankruptcy proceedings] will bar a third identical action in the federal court. Even if that determination was erroneous, this court, and the appellants, are bound by it.").

56 In fact, that's what did happen in Parsons Steel. And it's that procedural irregularity that probably has caused some confusion in lower courts. It's also quite possible, from the principles discussed above, that some states would treat interlocutory denials as final enough. 
Therefore, the federal court is barred by the Full Faith and Credit Act from issuing an injunction because doing so would not give the Oklahoma ruling the same preclusive effect it would get in state courts. Let's see how this plays out: ${ }^{57}$

Scenario One: Preclusive Ruling in State Court Triggers Full Faith and Credit

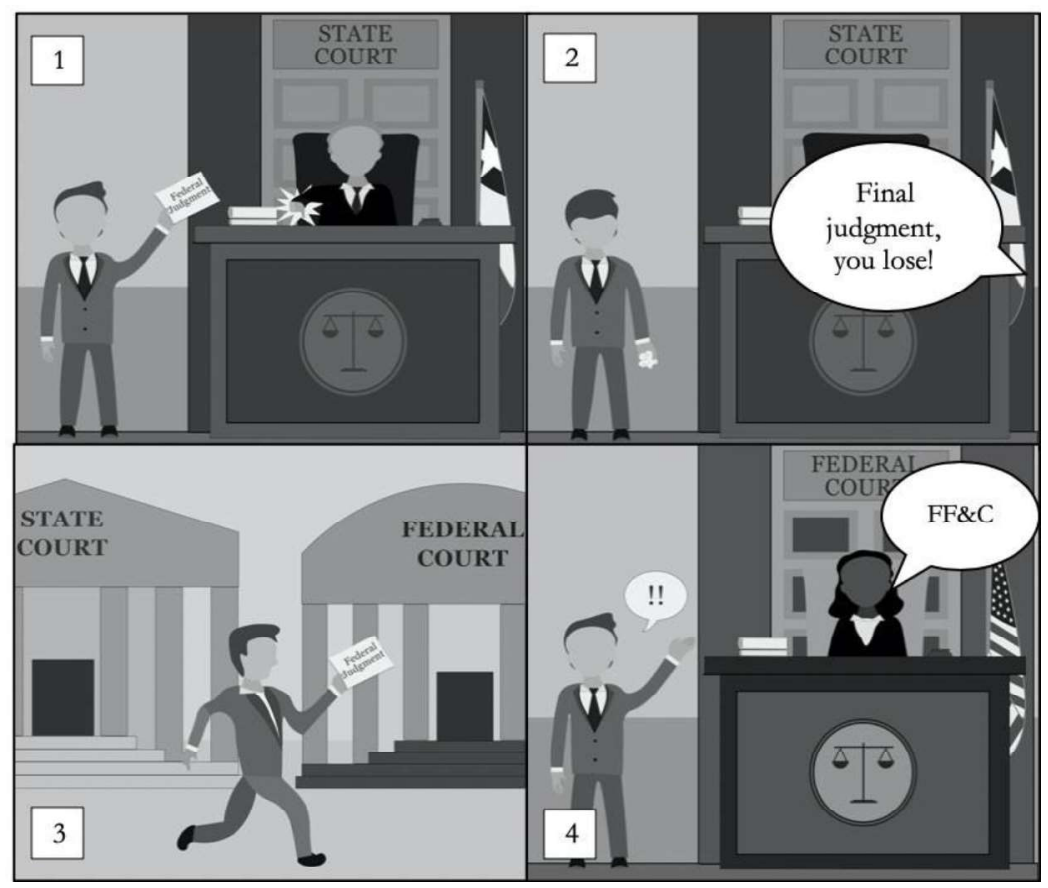

The harder situation is where we turn in Part IV, just after Parsons Steel. In Part IV, we encounter the situation where Fred bites the apple in Oklahoma state court, loses, and then returns to federal court. But in this harder scenario, Oklahoma state law would not treat the preclusion ruling as "final" for issue preclusion because Fred ran faster-seeking the federal injunction after the state court denies his preclusion defense but before it disposed of all claims against all parties. The key difference between these two situations is that in Parsons Steel, the Full Faith and Credit Act does the work. In the latter, as we shall see, it's not Full Faith and Credit, but comity. Again, visually:

57 A special thank-you to Juliana Longoria for creating the images depicted in Scenarios One and Two. 
Scenario Two: Litigant Returns to Federal Court after Interlocutory Denial of Preclusion Defense

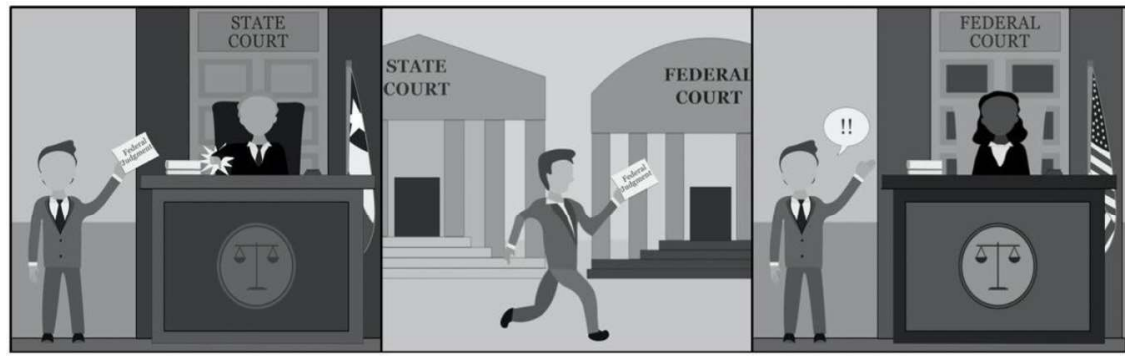

\section{B. Parsons Steel}

Parsons Steel sued First Alabama Bank in Alabama state court for fraud. ${ }^{58}$ While that suit was pending, Parsons Steel filed an action against the bank in federal court, alleging the same facts but claiming the bank had violated federal law. ${ }^{59}$ The federal suit went to trial first, and the court granted judgment notwithstanding the verdict to the bank.$^{60}$ With a federal judgment in its back pocket, the bank returned to state court and pleaded a preclusion defense to dismiss the action, but the state court denied its motion. ${ }^{61}$ The state court jury returned a verdict in favor of Parsons Steel, and judgment was entered accordingly. ${ }^{62}$ After all this happened-including judgment on a jury verdict - the bank ran back to the judgment-rendering district court and sought injunctive relief under the relitigation exception, which the court granted, and the Eleventh Circuit affirmed. ${ }^{63}$ In other words, the procedural posture of this case mirrored the Scenario One diagram from the preceding section.

The issue before the Supreme Court was narrow: whether the federal district court properly enjoined the state court proceedings without first considering the possible preclusive effect of the Alabama state court's

\footnotetext{
58 Parsons Steel, Inc. v. First Ala. Bank, 474 U.S. 518, 520 (1986).

59 Id.

$60 \quad I d$.

$61 \quad I d$.

$62 \quad I d$.

$63 I d$. at $520-22$.
} 
judgment, including its resolution of the bank's preclusion defense. ${ }^{64}$ Concluding that the Eleventh Circuit "gave unwarrantedly short shrift to the important values ... embodied in the Full Faith and Credit Act," ${ }^{65}$ the Court reversed and remanded the case so that the district court could consider the possible preclusive effect under Alabama law of the state court judgment. ${ }^{66}$ Rejecting the notion that the Anti-Injunction Act operated as an implicit exception to the Full Faith and Credit Act, the Court explained:

We believe that the Anti-Injunction Act and the Full Faith and Credit Act can be construed consistently, simply by limiting the relitigation exception of the Anti-Injunction Act to those situations in which the state court has not yet ruled on the merits of the res judicata issue. Once the state court has finally rejected a claim of res judicata, then the Full Faith and Credit Act becomes applicable and federal courts must turn to state law to determine the preclusive effect of the state court's decision. ${ }^{67}$

Close to thirty-five years have elapsed since the Court's decision in Parsons Steel, so there is little point in painstakingly combing through the opinion to fill in its gaps. On the one hand, the Court's opinion seems to acknowledge the common-sense comity due by limiting a relitigation exception "to those situations in which the state court has not yet ruled on the merits of the res judicata issue." 68 The term "ruled" is not necessarily a term of art, so when viewed in isolation, it suggests that a state court's rejection of a preclusion defense by a party that prevailed in federal court precludes a federal injunction altogether. ${ }^{69}$

The Supreme Court went on to explain, however, that once the state court has "finally rejected" the preclusion defense, ${ }^{70}$ then federal courts must determine the preclusive effect of that decision under the Full Faith and Credit Act. ${ }^{71}$ The language in the opinion presupposes the existence of a state

$64 \quad$ Id. at 522.

$65 I d$. at 523

66 Id. at $525-26$

67 Id. at 524 (emphasis added)

68 Id. at 524.

69 See Fernández-Vargas v. Pfizer, 522 F.3d 55, 68 (1st Cir. 2008) ("[T]he court must remain mindful that the state court's rejection of a preclusion defense effectively proscribes a federal court from issuing a subsequent injunction to effectuate its judgment.").

70 Also unanswered in Parsons Steel is whether state or federal law governs the question of whether the state court "finally rejected" the res judicata defense. See Duffy \& McGovern Accommodation Servs. v. QCI Marine Offshore, Inc., 448 F.3d 825, 828 (5th Cir. 2006) ("It is unclear from Parsons Steel whether state or federal law determines whether the state court has 'finally rejected' the claim that the federal order is preclusive, leading to application of state preclusion law.").

71 Parsons Steel, 474 U.S. at 524. 
court judgment because those were the facts before the Court; ${ }^{72}$ however, it did not address the situation in which the state court's denial of the preclusion defense is just interlocutory. Thus, while preclusion principles "largely obviate[] the risk of conflicting final dispositions on the merits, a significant risk of conflict attends interlocutory rulings that are not ordinarily entitled to preclusive effect." 73

So, Parsons Steel teaches that a federal court cannot enter an injunction under the relitigation exception if the state court has already resolved the underlying preclusion issue in a ruling that would be issue preclusive under state law. Stated far more simply, the relitigation exception is not an exception to the Full Faith and Credit Act. ${ }^{74}$ This holding, though seemingly straightforward, has still been misapplied. ${ }^{75}$

But Parsons Steel failed to answer two questions. First, it did nothing to explain what type of preclusion denials are "final." The reason, of course, is Parsons Steel cannot answer that question because it's a matter of state law. ${ }^{76}$ Second, and our reason for writing this Article: Parsons Steel does not hold that a district court is entitled to issue an injunction under the relitigation exception simply because a state court's preclusion ruling is not dispositive under the Full Faith and Credit Act.

\footnotetext{
72 See id. at 526.

73 Lumen Constr., Inc. v. Brant Constr. Co., Inc., 780 F.2d 691, 694 n.2 (7th Cir. 1985) (emphasis added).

74 Parsons Steel, 474 U.S. at 524.

75 The Eighth Circuit, for example, failed to consider the possible preclusive effect of a state court ruling before holding that a federal injunction was warranted. See In re SDDS, Inc., 97 F.3d 1030, 1037 41 (8th Cir. 1996). The Eighth Circuit reviewed a district court's refusal to issue an injunction against state court proceedings that were already under review by the South Dakota Supreme Court after a grant of summary judgment. $I d$. at 1034,1039 . There were no doubts that the summary judgment was a final judgment, but the Eighth Circuit did not attempt to determine whether that judgment was entitled to preclusive effect under South Dakota law. The only mention of Parsons Steel came in a footnote, where the court stated that " $[\mathrm{b}]$ ecause the South Dakota trial court did not rule on the claim preclusive effect of SDDS $V I \ldots$ [it was] not precluded from protecting [its] judgment in $S D D S V I$ under the relitigation exception to the Anti-Injunction Act." Id. at 1039 n. 14. After the Eighth Circuit issued the writ of mandamus directing the district court to grant the injunction, the South Dakota Supreme Court declared that had it been able to reach the merits of the claim, "analysis of [its] own case law may have produced a different result" than in federal court. SDDS, Inc. v. State, 569 N.W.2d 289, 293 n.9 (S.D. 1997). Surprisingly, the State's writ of certiorari to the U.S. Supreme Court did not state as a ground the Eighth Circuit's failure to consider the possible preclusive effect of the state court judgment pursuant to Parsons Steel. See In re SDDS, Inc., 225 F.3d 970 (8th Cir. 1996), petition for cert. filed, 2001 WL 34117697 (U.S. Feb. 6, 2001) (No. 00-1273).

76 Parsons Steel, 474 U.S. at 525.
} 


\section{COMity ANd INTERlocutory PREClusion Denials}

For those jumping right to this Part IV, let's set the stage and review how we got here. Fred and Dave have related suits pending in state court and federal court. Fred wins a judgment in federal court and wants to end the state court proceedings. And we'll assume that Fred has the option of either (A) raising the defense in state court, or (B) seeking an injunction under the relitigation exception from the federal district court that rendered the judgment. Fred chooses option (A) and raises his preclusion defense in state court. Conceptually, we distinguished between two scenarios. The first is the focus of the previous section, and the second is what we address below:

(1) Assume that under state law, the denial of Fred's preclusion defense would be considered preclusive. This scenario is answered by Parsons Steel. The Full Faith and Credit Act demands that the federal court refuse to issue the injunction (Part III, above).

(2) Assume that under state law, the state court's denial of his preclusion defense would not be considered itself "final" enough to be preclusive until it merges into a later judgment. ${ }^{77}$ Restated, unlike in the Parsons Steel case, in our scenario Fred returns for a relitigation exception after losing in state court but, cleverly, before that state-court preclusion ruling merges into the judgment.

To this second situation, we turn and say: Although the Full Faith and Credit Act does not bar Fred's follow-up request for the federal injunction, principles of equity and comity do bar such a two-bites-at-the-apple approach, absent extraordinary circumstances. Or, to put it in the words of our introductory dialogue: Once you ask mom, dad shouldn't even entertain the question, much less overrule mom, absent extraordinary circumstances. To support our position, the following subsections establish (a) the AntiInjunction Act is not the only obstacle, and satisfying one of its exceptions only removes its bar; (b) in most cases, the relitigation injunction should not issue because the movant has an adequate remedy at law that it already elected to exercise; (c) the statutory language and history of the AntiInjunction Act support our approach; and (d) the post-Parsons Steel circuit court cases demonstrate that only analytical oversights and missteps have generated contrary results. 


\section{A. Injunctions, Bars, and Permissions}

In our view, courts have shown an alarming willingness to allow the federal dad to overrule the state mom so long as "technically" the state court's rejection of preclusion isn't "final" for issue-preclusion purposes. It seems, stated simply, better in every respect to say:

Federal courts should honor the state court's unambiguous denial.

If the state court revisits the inquiry, so may the federal court. But given federal-state comity, the federal court should trust that the state court appreciates the magnitude of its denial and would not have done so flippantly.

Let's be clear about two things: (1) Parsons Steel's Full Faith and Credit rationale does not strictly apply if state law would treat the denial of preclusive effect as nonfinal; and (2) if we construe Parsons Steel to strictly define the only time a relitigation exception is barred by a state preclusion ruling, then contrary to Parsons Steel's spirit, comity, and common sense, federal judgment holders usually have two bites at the apple, so long as they move quickly. ${ }^{78}$ Consider the way parallel proceedings usually progress: a state suit is pending, and a party obtains a federal judgment. If the party wins in state court, then the party wins. But if the party loses, that loss will be a denial of a motion for summary judgment or a motion to dismiss that, by some accounts, will always be interlocutory.

If Parsons Steel and its Full Faith and Credit rationale doesn't bar the injunction under the relitigation exception, then why should a federal court refuse? Let's reset. There is no Injunction Act. Nor does the Judicial Code contain a Relitigation Act. Rather, the history of law and equity, combined with the All Writs Act, authorize and limit injunctive relief. ${ }^{79}$ The AntiInjunction Act is another limit-a statutory bar to certain injunctions. If that Act contains an exception, and if that exception is satisfied, the result is merely lifting that particular bar. This distinction, though logically compelled and unimpeachable ${ }^{80}$ — seemingly evades the courts that generally

78 This is less true but reaches the same desirable result, in places where courts appropriately treat interlocutory rulings as final enough for Full Faith and Credit purposes. But see Metromedia Co. v. Fugazy, 983 F.2d 350, 366 (2d Cir. 1992) (explaining that issue preclusion can apply even absent a final judgment); Diane P. Wood, Fine-Tuning Judicial Federalism: A Proposal for Reform of the Anti-Injunction Act, 1990 BYUL. REV. 289, 306 (1990).

7928 U.S.C. $\$ 1651$ (1949).

80 Atl. Coast Line R.R. Co., v. Bhd. of Locomotive Eng'rs, 398 U.S. 281, 286-87 (1970). 
permit these injunctions. ${ }^{81}$ The correct inquiry does not begin and end with whether there's an exception to the Anti-Injunction Act because that inquiry doesn't ask about the other requirements of our federal system or for equitable relief. By switching a few words and a punctuation mark in our decisional tree, we can highlight the fundamental problem with some approaches. Substitute the italics for the struck-out text, and you go from wrong to correct.

(1) Does the Anti-Injunction Act Apply?

- No - The Act doesn't bar the injunction (but you still have to show you're entitled to one).

- Yes - Go to Step 2.

(2) Does the movant satisfy an exception?

- No - The Act bars the injunction.

- Yes - The party is entitled to an injunction. ${ }^{82}$ Is the party entitled to an injunction $?^{83}$

The Mitchum line of cases confirms that parties do not prove themselves entitled to an injunction merely by satisfying an exception to the Act. The Mitchum Court held that 42 U.S.C. Section 1983 contained an "express authorization," which is the first enumerated exception. ${ }^{84}$ Therefore, the Court concluded, the Anti-Injunction Act itself did not bar a party from enjoining allegedly unconstitutional state criminal proceedings. But the Court quickly noted that principles of equity and comity barred most such injunctions under principles now known as "Younger abstention." ${ }^{85}$ While different principles of equity and comity apply to criminal proceedings versus civil proceedings, ${ }^{86}$ the point is that the Court held, and has continued to hold, that removing the Anti-Injunction Act bar does not entitle the movant to an injunction. ${ }^{87}$

81 See infra Part IV.D.1

82 The (incorrect) approach taken by many circuit courts. See infra Part IV.D.1.

83 The correct approach. See infra Part IV.D.2.

8428 U.S.C. $\$ 2283$ (1948); see also Mitchum v. Foster, 407 U.S. 225, 243 (1972).

85 Younger v. Harris, 401 U.S. 37, 43-54 (1971); see also H.C. v. Koppel, 203 F.3d 610, 613 (9th Cir. 2000) (explaining the Younger doctrine).

86 See Sprint Commc'ns Inc. v. Jacobs, 571 U.S. 69, 78 (2013) (limiting the scope of Younger abstention in civil cases to certain enforcement proceedings and cases affecting a state court's ability to perform judicial functions). But see Pennzoil Co. v. Texaco, Inc., 481 U.S. 1, 11 (1987) (mandating application of Younger abstention in civil proceedings where the "exercise of the federal judicial power would disregard the comity between the States and the National Government.")

87 Parsons Steel, Inc. v. First Ala. Bank, 474 U.S. 518, 526 (1986) (citing Mitchum v. Foster, 407 U.S. 225, 243 (1972)). 
To enjoin a pending state suit is to call in the heaviest artillery. And to find such artillery authorized categorically by an exception to a bar would give "unwarrantedly short shrift to the important values of federalism and comity." ${ }^{88}$ Lest the relitigation exception be turned on its head, federal district courts should typically abstain from enjoining a state court proceeding once the state court has expressly and unambiguously rejected a preclusion defense, even if the rejection is interlocutory. ${ }^{89}$ Merely because a district court believes the elements of claim or issue preclusion are met does not alone justify an injunction under the relitigation exception. ${ }^{90}$ Only under a narrow set of extraordinary circumstances-mainly vexatious, baseless, or harassing litigation-should a district court be able to enjoin a state court proceeding after the denial of a preclusion defense. ${ }^{91}$

\section{B. Adequate Remedies at Law}

Usually, a party that has already lost its preclusion argument in state court should lose when the party later seeks a federal injunction. In most cases, that party should lose because it cannot satisfy the traditional equitable adequate-alternative-remedies inquiry ${ }^{92}$ But usually doesn't mean never.

\section{Usually}

Relitigation injunctions are strange even when the to-be-enjoined state court has not already ruled on the preclusion defense. As Professor Redish observes, if the federal judicial system entrusts to state courts "the evolution of federal law," then it should have no problem trusting their ability to correctly apply the doctrine of preclusion. ${ }^{93}$ In the ordinary relitigationexception scenario, the federal judgment holder has the choice to raise preclusion in the state court or seek an injunction from the court that rendered the judgment. The problem of course, even without introducing the two-bites problem, is that the judgment holder has an adequate alternative remedy at law. Indeed, by definition, the Anti-Injunction Act does not even apply unless

88 Id. at 523.

89 See Ramsden v. AgriBank, FCB, 214 F.3d 865, 870 (7th Cir. 2000).

90 See Parsons Steel, 474 U.S. at 525 (concluding that the state court's mistaken rejection of a res judicata claim "does not justify the highly intrusive remedy of a federal-court injunction")

91 See infra Part IV.B.2.

92 See Continental Cas. Co. v. Yerxa, 16 F.2d 473, 475 (Mass. Dist. Ct. 1926); Watson v. Sutherland, 72 U.S.74, 78 (1866).

93 Redish, supra note 7, at 724; see also 17A CHARLES ALAN WRIGHT ET AL., FEDERAL PRACTICE AND PROCEDURE $\S 4226$ n.33 (3d ed. 2019), Westlaw (database updated Oct. 20). 
a state court proceeding is already pending. And so, it would seem even without a failed first attempt in state court, the relitigation exception ought to be invoked rarely-only when the inadequacy of the state option is articulated. ${ }^{94}$

But whatever debate might exist about the purpose of the Act and its shift in the federalism balance, and whether that means relitigation injunctions should issue as an initial option, once the party has already raised its preclusion defense in state court, the adequate-remedy requirement should usually be determinative. After all, the party has argued preclusion in state court (an opportunity) and lost. If the injunction is to issue, the only rationale would be that the state court was inadequate because the court misapplied the law. ${ }^{95}$ Here is how the hearing would likely proceed in federal court, consistent with our opening dialogue:

Lawyer: I need an injunction to protect your judgment.

Judge: Do you have an adequate remedy by raising it in state court?

Lawyer: No.

Judge: Why not?

Lawyer: Because I already tried that.

Judge: So, that's not adequate because...?

94 It has been argued that the relitigation exception is undesirable, and that where there is another remedy, such as a plea of res judicata in the state court, the federal court, out of proper deference for the court of the state, should not stay the state proceedings. Law Review Editors, Comment, Anti-Suit Injunction Between Federal and State Court, 32 U. CHI. L. REv. 471, 485 (1965). Ordinarily a federal court would and should so defer. The requirements of irreparable harm and lack of any other adequate remedy apply implicitly under the present statute—e.g., So. Cal. Petroleum Corp. v. Harper, 273 F.2d 715, 719 (5th Cir.1960); Texaco, Inc. v. Fiumara, 248 F. Supp. 595 (E.D. Pa. 1965) - and will continue to apply under this draft. But power should exist to grant the injunction in the unusual case where those requirements are met. American Law Institute, Study of the Division of JuRisdiction Between State and FEDERAL COURTS, Official Draft 1969 at 306; cf. Bob Jones Univ. v. Simon, 416 U.S. 725,742 n.16 (1974) ("The Anti-Injunction Act was written against the background of general equitable principles disfavoring the issuance of federal injunctions against taxes, absent clear proof that available remedies at law were inadequate.")

95 Lear, Inc. v. Adkins, 395 U.S. 653, 675 (1969) (" $[E]$ ven though an important question of federal law underlies ... the controversy, [state courts will] define the extent, if any, to which the states may properly act to enforce the contractual rights of inventors of unpatented secret ideas."); $c f .18$ CHARLES Alan Wright et al., Federal Practice and Procedure $§ 4405.1$ (3d ed.), Westlaw (database updated Aug. 2019). 
Lawyer: Well, because I lost.

Judge: Have I ever told you the story about the kid who asked his dad if he could go to the big party after his mom said "no"?

Indeed, similar sentiments about the need to enjoin rogue state courts were raised and rejected in both Atlantic Coast Lines ${ }^{97}$ and Parsons Steel. ${ }^{98}$ The Court clarified in Atlantic Coast Line: Even a federal court's unwavering certainty that a state court made a mistake does not itself justify an injunction under the relitigation exception. ${ }^{99}$ Even if a state decision is surely wrong, federal district courts are powerless to act as appellate courts and sit in review of state court decisions. ${ }^{100}$ Similarly, the Parsons Steel Court dismissed the notion that the relitigation exception is somehow a vehicle authorizing federal courts to address the inefficiencies of parallel litigation, such as if a state court disagrees with the preclusive effect of a federal judgment. The focus of the relitigation exception, both before and after Parsons Steel, has always been exclusively to prevent state court interference that "seriously impair[s]" a federal court's ability to decide a case. ${ }^{101}$

Some courts have mistakenly suggested that the relitigation exception is somehow the one area where a party needn't show a lack of adequate remedies. ${ }^{102}$ There is little to gain by studying such opinions, as they usually ${ }^{103}$ lack both rationale and rigor. It's an unfortunate headnote that

96 See supra Part I.

97 Atl. Coast Line R.R. Co., v. Bhd. of Locomotive Eng'rs, 398 U.S. 281, 283 (1970).

98 Parsons Steel, Inc. v. First Ala. Bank, 474 U.S. 518, 519 (1986)

99 Atl. Coast Line R.R. Co., 398 U.S. at 296.

100 Id. at 296

101 Parsons Steel, 474 U.S. at 525.

102 See, e.g., Prime Ins. Syndicate, Inc. v. Orleans Limousines \& Transp., Inc., No. 07-604, 2007 WL 914177, at *2 (E.D. La. Mar. 23, 2007) (citing Ballenger v. Mobil Oil Corp., 138 Fed. Appx. 615 (5th Cir. 2005)).

103 With an exception in Toucey v. New York Life Ins. Co., 314 U.S. 118, 144 (1941) (Reed, J., dissenting). As Justice Reed noted in his dissent, without the relitigation exception, a litigant's only resource to preserve the finality of a prior federal judgment would be a plea of preclusion in the state court proceeding. He also argued that this remedy would be inadequate because the subsequent court-in this context a state court-would be "unfamiliar with the record already made." However, the same could be said of the first court, the district court, being unfamiliar with the record in the subsequent state proceedings. Familiarity with the record aside, under traditional practice, the court in the subsequent proceeding typically decides the preclusion defense rather than the court in the prior proceeding deciding the preclusive effect of its own rulings. So, unless Justice Reed intended to imply that state courts are illequipped to accurately decide the preclusive effect of federal court judgments, no reason exists to lose trust in state courts' ability to apply the rules of preclusion. 
should be corrected anywhere it appears. To accept such a misguided shortcut past the showing usually required, the Court would have to ignore centuries of equity and accept the following two-step, which accounts for the Mitchum decision:

a) A party must satisfy the traditional concerns of equity when seeking an injunction expressly authorized by the civilrights laws (Mitchum); ${ }^{104}$

b) But if instead an injunction protects preclusive effect, (rather than merely preventing civil-rights violations), ${ }^{105}$ then no independent showing is needed. ${ }^{106}$

That approach cannot survive Mitchum or other relitigation precedent. ${ }^{107}$ Mitchum's express references to the general principles of equity that must always restrain a federal court from enjoining a state court implies as much, ${ }^{108}$ and the absence of anything contrary in the text of Section 2283 reaffirms it.

One important note to make-nothing in the text of the 1948 revisions or the Reviser's Notes reveals a congressional intent to paint a preclusion defense in state court as inferior to a federal injunction under the relitigation exception. ${ }^{109}$ The revisions were designed only to incorporate the (judicially created) relitigation exception as it was understood before the Toucey decision, which makes no reference to the adequacy of a preclusion defense in state court. ${ }^{110}$ In fact, the codification of the Act's exceptions did not alter the understanding that federal courts must exercise great caution before interfering with state court proceedings, in part because of the ability to raise a preclusion defense. ${ }^{11}$

104 See Mitchum v. Foster, 407 U.S. 225, 243 (1972).

105 See Sarcasm, MERRIAM-WebSTER DictionARY (11th ed. 2003).

106 Ballenger, 138 Fed. Appx. at 622.

107 See infra Part IV.C.

108 Mitchum, 407 U.S. at 243; see also Merle Norman Cosmetics, Inc. v. Victa, 936 F.2d 466, 468 (9th Cir. 1991).

109 Redish, supra note 7, at 724 ("Since the framing of the Constitution, however, state courts have been considered-rightly or wrongly-to be appropriate enforcers of federal law.").

110 Reviser's Note to 28 U.S.C. $§ 2283$, H.R. REP. No. 308, at A181-A182 (1947) ("The exceptions specifically include the words 'to protect or effectuate its judgments,' for lack of which the Supreme Court held that the Federal courts are without power to enjoin relitigation of cases and controversies fully adjudicated by such courts... [T] he revised section restores the basic law as generally understood and interpreted prior to the Toucey decision.").

111 See, e.g., So. Cal. Petroleum Corp. v. Harper, 273 F.2d 715, 718-19 (5th Cir. 1960); Int'1 Ass'n of Machinists \& Aerospace Workers v. Nix, 512 F.2d 125, 131 n.9 (5th Cir. 1975). 
But as noted above, even if a party finds itself litigating in a circuit that mistakenly exempts some relitigation injunctions from the adequatealternative-remedies showing, a sensible distinction exists in the two-bites cases at issue. Later courts should not balk at distinguishing those cases from the more intrusive constructive appeals. That is, even if a panel is stuck with the general rule that no alternative-remedy showing is needed when the judgment holder comes first to federal court, that rationale shouldn't extend to a circumstance when the state court has already ruled. ${ }^{112}$

\section{Sometimes}

Usually, we've said, two bites shouldn't be available. That default is justified by a policy that applies in all parallel-proceedings environments, not just the relitigation exception. Stated simply: the party asking a federal court for an injunction on a point of law already could have-and did-ask the state court to answer that question. Regardless of context, assuming state court incompetency or, more literally, inadequacy is a nonstarter.

But sometimes, a party seeks federal help to end parallel proceedings for different reasons. A fairly accurate test would be to distill the party's argument to the essence. If the argument is "the state court will (or did) get it wrong," federal relief will be unavailable.

Take Younger v. Harris. In Younger, the Court established that district courts generally cannot enjoin pending state prosecutions alleged to be illegal. ${ }^{113}$ Even though the plaintiff sought the injunction under Section 1983, which is an expressly authorized exception to the Anti-Injunction Act, the Court refused to enjoin the prosecution. Noting principles of equity and comity, the Court refused to presume that the state court and its appellate process were inadequate alternative remedies. ${ }^{114}$ The principles from Younger translate seamlessly to this context. A federal judgment holder has an opportunity to raise the preclusion defense in state court with review from that state's appellate courts and the Supreme Court, ${ }^{115}$ the adequacy of which was never questioned by the 1948 amendments that created the relitigation exception. ${ }^{116}$

112 That preclusion ruling, though decided in state court, is a matter of federal law. And so not only will that ruling be appealable through the state system, but it also can raise the federal issue warranting the Supreme Court's Certiorari jurisdiction.

113 Younger v. Harris, 401 U.S. 37, 53-54 (1971).

114 Id. at $43-44$

115 Atl. Coast Line R.R. Co. v. Bhd. of Locomotive Eng'rs, 398 U.S. 281, 287 (1970).

116 See supra Part IV.B.1. And like in Younger, subsequent state proceedings often involve claims and issues not indisputably barred by preclusion, evidenced by what we can only assume is a good faith 
But the Younger Court also cited approvingly its earlier Dombrowski ${ }^{117}$ case. There, the party asked the federal court to enjoin the state criminal litigation because it was harassing, repetitive, and not a good faith try to secure a conviction. ${ }^{118}$ Instead, the repeated state court prosecutions were threatening and harassing attempts whose effectiveness did not depend upon the state judges correctly applying the law. ${ }^{119}$ The injunction was proper because the prosecution was brought in "bad faith" and was unimpacted by whether the state judge ultimately applied the law correctly. ${ }^{120}$

Although it's difficult to imagine too many circumstances where a second-bite injunction would be warranted, vexatious litigation ${ }^{121}$ could be one. In fact, courts have historically interpreted the Anti-Injunction Act to permit federal injunctions when the state court proceedings sought to be enjoined are harassing, baseless, or vexatious. ${ }^{122}$ And this makes sense, especially considering the directive in Parsons Steel that principles of equity and comity ought to restrain a federal court's discretion to issue an injunction under the relitigation exception. ${ }^{123}$ Extraordinary circumstances like vexatious litigation push back on the very principles of equity and comity that already place a thumb on the scale against the issuance of an injunction in the first place. This idea is not exclusive to the relitigation exception, and it stems from the foundational recognition that parties who use litigation as a vehicle of abuse and harassment "threaten the integrity of the judicial system" altogether. ${ }^{124}$

denial by the state court on the preclusion issue. Moreover, any added expense and time spent litigating the subsequent state court proceeding is incidental to lawsuits brought in good faith because, as the Parsons Steel Court explained, "inefficient simultaneous litigation in state and federal courts on the same issue ... is one of the costs of [this country's] dual court system." Parsons Steel, Inc. v. First Ala. Bank, 474 U.S. 518, 524-25 (1986).

117 See generally Dombrowski v. Pfister, 380 U.S. 479 (1965).

118 Id. at 482.

119 Id.

$120 \quad$ Id. at 490

121 Ramsden v. AgriBank, FCB, 214 F.3d 865, 870 (7th Cir. 2000).

122 See Am. Optometric Ass'n v. Ritholz, 101 F.2d 883, 886-87 (7th Cir. 1939); Browning Debenture Holders' Comm. v. DASA Corp., 454 F. Supp. 88, 100-01 (S.D.N.Y. 1978); 600 Cal. Co. v. Harjean Co., 284 F. Supp. 843, 861-62 (N.D. Tex. 1968).

123 Parsons Steel, Inc. v. First Ala. Bank, 474 U.S. 518, 526 (1986)

124 Davis v. State, Civ. No. 15-377-SLR, Civ. No. 15-384-SLR, 2015 WL 4477701, at*1 (D. Del. July 22, 2015) (mem. op.); accord Vendo Co. v. Lektro-Vend Corp., 433 U.S. 623, 632 (1977) (Blackmun, J. concurring) (explaining that when state courts are used as the tool of a vexatious or harassing litigant, an injunction can issue because defending each state court suit wouldn't solve the problem, even if each state court ruled correctly); see generally Wright \& MILLER, AVAILABILITY OF INJUNCTIVE RELIEFADEQUACY OF THE LEGAL REMEDY $§ 2944$ (3d ed. 2020). 


\section{Historical Practice}

The Anti-Injunction Act is not merely based on concerns of comity, but it "is essentially a rule of comity." 225 Accordingly, the Supreme Court has consistently emphasized that district courts must resolve doubts against injunctions and construe exceptions strictly and narrowly. ${ }^{126}$ It's no surprise then that historical practice predating even Atlantic Coast Line was characterized by a reluctance to interfere with state court proceedings. ${ }^{127}$ The Supreme Court said it best as early as 1955: "The prohibition of [the AntiInjunction Act] is but continuing evidence of confidence in the state courts, reinforced by a desire to avoid direct conflicts between the state and federal courts. We cannot assume that this confidence has been misplaced." 228 When federal courts issue injunctions after the state court unambiguously considers and disagrees on the preclusion issue, they undermine this confidence and assert a superiority over state courts that they do not have. ${ }^{129}$

Even before Parsons Steel, courts refused to issue injunctions against ongoing state court proceedings when the ability to raise the federal judgment as a preclusion defense appeared to be an adequate remedy. ${ }^{130}$ But certain courts seem to throw all those considerations out the window by upholding these intrusive injunctions simply because the elements of claim or issue preclusion are not met, yet failing to weigh the interests of comity and federalism with the interest of preventing possible relitigation. ${ }^{131}$

The Fifth Circuit, for example, has affirmed second-bite injunctions simply because it concluded that state courts wrongly denied a preclusion defense. In Vines v. Univ. of Louisiana, ${ }^{132}$ for example, the Fifth Circuit ordered a district court to issue an injunction against state court proceedings simply because-from its perspective- "all of the elements of collateral

125 S. Cal. Petroleum Corp. v. Harper, 273 F.2d 715, 718 (5th Cir. 1960) (emphasis added).

126 Goodridge v. Harvey Grp. Inc., 602 F. Supp. 78, 80 (S.D.N.Y. 1985) (citing Atl. Coast Line

R.R. Co. v. Bhd. of Locomotive Eng'rs, 398 U.S. 281, 287 (1970))

127 See id.

128 Amalgamated Clothing Workers v. Richman Bros., 348 U.S. 511, 518 (1955)

129 See Lion Bonding \& Sur. Co. v. Karatz, 262 U.S. 77, 90 (1923) ("Lower federal courts are not superior to state courts.").

$130 \quad$ E.g., Delta Air Lines v. McCoy Rests., 708 F.2d 582, 585 (11th Cir. 1983); Harper, 273 F.2d at 719; Texaco, Inc. v. Fiumara, 248 F. Supp. 595, 597 (E.D. Pa. 1965) ("There is no reason for me to assume that my equally able colleagues on the state court would not honor or comprehend any appropriate defense of collateral estoppel or res judicata.").

131 See, e.g., Vines v. Univ. of La., 398 F.3d 700, 712 (5th Cir. 2005).

132 Id. 
estoppel ha[d] been satisfied." 133 In that case, even the Louisiana Court of Appeals had already determined that the prior federal judgment did not bar the claims brought in the subsequent state action, but the Fifth Circuit still refused to give preclusive effect to that decision. ${ }^{134}$ Not only did the Fifth Circuit fail to review the district court's refusal of an injunction under the proper abuse of discretion standard, ${ }^{135}$ it refused to mention whether the injunction was proper, considering the interests of comity and federalism as Parsons Steel requires. In other words, the court ordered the injunction simply because the case fell within an exception to the Anti-Injunction Act, which does not address "in any way the principles of equity, comity, and federalism that must restrain a federal court when asked to enjoin a state court proceeding." 136

In Atlantic Coast Line, the Court made the point that "federal court[s] do[] not have inherent power . . . to enjoin state court proceedings merely because those proceedings interfere with a protected federal right or invade an area preempted by federal law, even when the interference is unmistakably clear." 137 Translated to this context: federal courts similarly do not have the inherent power to ignore the limitations of the Anti-Injunction Act and enjoin state court proceedings merely because they disagree with the state court's interlocutory preclusion ruling, even if they believe the ruling is unmistakably incorrect. ${ }^{138}$

133 Id. However, there was considerable disagreement in the state and federal system, both at the trial and appellate levels, as to whether the state court claims were completely barred by preclusion.

134 Id. at 705-06.

135 Id. at 704. While it is true that whether a district court's injunction falls within the scope of the Anti-Injunction Act is a question of law subject to de novo review, see Next Level Commc'ns LP v. DSC Commc'ns Corp., 179 F.3d 244, 249 (5th Cir. 1999), a decision to grant or deny an injunction under the relitigation exception is not a question of law. See Ballenger v. Mobil Oil Corp., 138 F. App'x. 615, 622 (5th Cir. 2005) (reviewing a district court's decision to grant an injunction under an abuse of discretion standard). Even assuming for argument's sake that it was a question of law, the proper remedy at the appellate level would be a remand for the district court to apply the correct legal principles and in its discretion decide the propriety of an injunction. See Duffy \& McGovern Accommodation Servs. v. QCI Marine Offshore, Inc., 448F.3d 825, 831 (5th Cir. 2006). Here, the Fifth Circuit essentially rendered a permanent injunction even under a de novo standard of review. Vines, 398 F.3d at 712-13.

136 Mitchum v. Foster, 407 U.S. 225, 243 (1972)

137 Atl. Coast Line R.R. Co. v. Bhd. of Locomotive Eng'rs, 398 U.S. 281, 294 (1970).

138 See Parsons Steel, Inc. v. First Ala. Bank, 474 U.S. 518, 525 (1986) ("Even if the state court mistakenly rejected respondents'claim of res judicata, this does not justify the highly intrusive remedy of a federal-court injunction against the enforcement of the state-court judgment.") 


\section{Beyond Preclusion: Clarity and Comity}

Although it is difficult to categorize neatly the different circuit courts' opinions, they can be generalized into two categories. Recall that the sequence is:

- Fred wins a federal judgment and believes its preclusive effect ends state court proceedings.

- Fred raises that preclusion defense in state court, but the state court denies Fred's motion (to dismiss or for summary judgment).

- Then, having already been rebuffed in state court, Fred seeks an injunction from the judgment-rendering federal court.

- Both parties and the federal judge agree, for argument's sake, that Fred would have been entitled to an injunction had Fred not raised preclusion in state court.

- The only issue is whether the state court's preclusion ruling prevents the federal court from issuing an injunction under the relitigation exception.

We start with the wrong approach, which we generalize as follows: a state court ruling on preclusion is irrelevant except to the extent that it is preclusive under state law. Then we'll return to the virtues of our approach.

\section{It's All About Preclusion?}

A modern Fifth Circuit opinion reveals much that's wrong about a liberal reading of the relitigation exception. In Duffy v. QCI, ${ }^{139} \mathrm{QCI}$ sued DMAS in Texas state court for breach of contract, but DMAS removed the action and won dismissal because a forum selection clause mandated venue in England. ${ }^{140}$ While the federal appeal was pending, QCI filed an almost identical breach of contract suit against DMAS in state court. DMAS raised, and the state court rejected, an issue preclusion defense. ${ }^{141}$ Having lost on preclusion, DMAS returned to federal court and sought an injunction based on the same preclusion argument the state court had just rejected. ${ }^{142}$

\footnotetext{
139 Duffy, 448 F.3d at 826

$140 \quad I d$.

141 Id.

142 Id.
} 
Concluding that its own order was not entitled to preclusive effect, the district judge refused to enjoin the state court proceedings. ${ }^{143}$

The Fifth Circuit reversed. Despite arguably contrary circuit authority, ${ }^{144}$ the Fifth Circuit held that the Texas state court's order was not entitled to preclusive effect because it was not a final judgment, and therefore Parsons Steel imposed no barrier. ${ }^{145}$ With little seeming connection to reality, the court noted-as though significant-that the state court did not issue a "reasoned opinion" and its decision was not immediately subject to appeal. ${ }^{146}$

The court might well have been wrong about Texas preclusion law and finality, but it was certainly wrong to end the analysis there.

If Duffy v. $Q C I$ is the law, then two bites are always available in similar all-about-preclusion jurisdictions. Why? Recall the scenarios when our federal judgment holder wants to end state proceedings because of a federal judgment, but wants two bites at the apple:

(1) The party raises preclusion in state court and wins dismissal. Then the party wins. ${ }^{147}$ It's over. The two-bites plan works, but the second bite was unnecessary.

(2) If the party raises preclusion in state court and loses, the loss will always be interlocutory (denial of a motion to dismiss or for summary judgment) and will almost never be accompanied by a reasoned opinion.

Win and you win, lose and you don't lose. It's borderline shocking that one could read Parsons, Atlantic Coastline, Younger, and similar cases-and still write Duffy v. $Q C I$.

\section{Gamesmanship and Purposeful Delay}

Since two bites can't hurt and can help, of course it encourages gamesmanship of the country's dual judicial system. Take the Eleventh

143 Id.

144 See Tex. Emp'rs Ins. Ass'n v. Jackson, 820 F.2d 1406, 1421 (5th Cir. 1987) (explaining that a state court's order needs to be final only in the sense that it is "beyond recall by the [issuing] court" for it to bind the federal court).

145 Duffy, 448 F.3d at 828-29.

$146 I d$. at $829 \mathrm{n} .12$ ("Here, although the parties were fully heard by the state court, the court did not provide any opinion, and the decision, although appealable after final judgment, is not currently appealable."). The court bent the very rule it used because Mower's "three-part test" asks whether the decision is subject to appeal or reviewed on appeal. Id. The test does not require the decision to be immediately appealable. Id. Therefore, the Fifth Circuit in reality based its conclusion on the fact that the state court did not issue an opinion, which is at best dumbfounding and at worst a trumped-up application of the law.

147 Not profound, but important 
Circuit, which was the first circuit court to address this question after the Supreme Court remanded Parsons Steel. The Eleventh Circuit took every opportunity to defend its previous decision, the main difference being that now it went through the formality of first determining the preclusive effect of the state court's resolution of the preclusion issue. ${ }^{148}$ In a brief, almost mordant manner, it stated: "[R]es judicata and collateral estoppel principles do not apply until there is a final judgment rendered on the merits of the case . . . . Denial of a motion for summary judgment is not a final judgment."149 Even though the Alabama state court had entered judgment on the verdict, the Eleventh Circuit equated finality with appealability, and the state judgment was non-appealable at the time of the injunction because post-trial motions had been filed. ${ }^{150}$ Having made the threshold determination that the state court's order was not entitled to Full Faith and Credit, the Eleventh Circuit found "no reason to alter [its] conclusion" about the propriety of the injunction. ${ }^{151}$ Injunction affirmed.

Although the Eleventh Circuit didn't discuss this, its interpretation all but guarantees that a federal court will never be bound by a state court's resolution of the preclusive effect of the former's judgments. As previously mentioned, state courts will rarely, if ever, simultaneously reject a party's preclusion defense and enter a final dispositive order in favor of the opposing party. Rather, the entire purpose of rejecting the preclusion defense is to permit the action to continue. However, even if the state court has already entered final judgment, the Eleventh Circuit's decision allows litigants to game the system by simply filing a post-trial motion in state court to make the judgment not currently appealable, then run to federal court for an injunction during the interim period that extends the state court's plenary powers. ${ }^{152}$ Surely, the fundamental principles of comity that gave rise to the Anti-Injunction Act are not so frail so as to be circumvented by simply filing a post-judgment motion for new trial. ${ }^{153}$

Cases out of the Ninth and Tenth Circuits show how courts could-and did-reject this tactic. In Sandpiper Village v. Louisiana-Pacific Corp., ${ }^{154}$ Louisiana Pacific Corp. ("L-P") sought to dismiss a Minnesota state court

148 First Ala. Bank v. Parsons Steel, Inc., 825 F.2d 1475, 1480 (11th Cir. 1987)

149 Id.

$150 \quad$ Id. at $1480-81$

151 Id. at 1484 .

152 See id. at $1480-81$.

153 Although it's beyond the strict scope of this Article, we'd be imprudent to not note, for those skipping around, that "finality" for issue preclusion isn't as simple as these opinions seem to suggest. Supra note 70 .

154 Sandpiper Vill. Condo. v. La.-Pac. Corp., 428 F.3d 831 (9th Cir. 2005). 
suit based on claims covered by a previous class settlement approved by Oregon's district court years earlier. ${ }^{155}$ The Minnesota court denied L-P's repeated motions for partial summary judgment based on preclusion but gave the jury a limiting instruction to not award damages covered by the previous federal settlement. ${ }^{156}$ Instead of seeking a federal injunction, L-P took the Minnesota case to verdict and lost. ${ }^{157}$ But before the verdict turned into a judgment, L-P persuaded the Oregon district court to enjoin the Minnesota state court from entering judgment on the portion of the jury's verdict purportedly barred by the previous settlement. ${ }^{158}$

The Ninth Circuit reversed and held that the relitigation exception was inapplicable for several reasons, chief among them that the Minnesota lawsuit did not challenge the class settlement's preclusive effect, and any potential relitigation of covered claims was addressed through the Minnesota court's limiting instructions. ${ }^{159}$ Most importantly, the Ninth Circuit stated that allowing L-P to lose on the merits in Minnesota, "yet run to federal court for an injunction just days before [judgment] . . . offends the very "principles of equity, comity, and federalism' that undergird the Anti-Injunction Act." 160 The district court's injunction under the circumstances amounted to a reversal of the Minnesota court on matters of Minnesota state law. ${ }^{161}$ By litigating in state court hoping to prevail but hedging its bets with a federal injunction following the jury's verdict, however, L-P wanted to have its cake and eat it too. ${ }^{162}$

Faced with similar facts, the Tenth Circuit in Bailey v. State Farm ${ }^{163}$ recognized that while it may be sensible to address a preclusion issue "just once" to give finality to federal judgments, simultaneous litigation on identical issues in state and federal courts is simply a cost of doing business in this country's dual court system. ${ }^{164}$ Relying on the Seventh Circuit's

155 Id. at 834

156 Id. at 837-38; see also Lester Bldg. Sys. v. La.-Pac. Corp., No. 43-C6-00-000335, 2004 WL 291998, at*3 (Minn. Ct. App. Feb. 17, 2004).

157 Sandpiper, 428 F.3d at 838 ("In other words, the jury determined as a factual matter that none of the repair costs were covered by the settlement.").

158 Id. at 839

159 Id. at 848,850

160 Id. at 851

161 Id. Concurring in the judgment, Judge Silverman would have adopted the Seventh Circuit's approach in Ramsden and held that "a state court action reaches [a] point of no return" and precludes federal intrusion "when the state court rules on the res judicata issue . . . regardless of whether a final judgment has been entered." Id. at 855 n. 1 (Silverman, J., concurring).

162 Id. at 853 (Silverman, J., concurring) ("[W] hat happens in state court stays in state court.").

163 See generally Bailey v. State Farm Fire \& Cas. Co., 414 F.3d 1187 (2005).

164 Id. at 1190 (emphasis added). 
reasoning in Ramsden, ${ }^{165}$ which this Article explains below is the model case for how to correctly approach this technical issue, the Tenth Circuit further explained that the amount of time the injunctive plaintiff waited before seeking an injunction was significant and encroached "on the delicate relationship between state and federal courts." ${ }^{166}$ Despite the questions that Parsons Steel left unanswered, it is inconceivable that the Supreme Court would ever interpret the relitigation exception to allow litigants to hedge their bets this way: continue litigating in state court in case you win on the merits, but if you lose, that second bite at the apple will be waiting for you in federal court.

Nothing about the relitigation exception context categorically answers the concerns of equity and comity that pervade the other areas governing federal-state interference and interaction. For example, even within the AntiInjunction Act context, finding an "expressly authorized" exception to the Anti-Injunction Act doesn't qualify in any way the principles of equity, comity, and federalism that must restrain a federal court when asked to enjoin a state court proceeding. Comity and federalism may not be a statutory bar to a federal injunction like the Full Faith and Credit Act, but they still create an important barrier. This interpretation is consistent with the Supreme Court's position on comity and abstention in other contexts, such as Colorado River and Burford. ${ }^{167}$ Even absent a final judgment on the merits that undeniably triggers preclusion principles, "[c]omity or abstention doctrines may ... permit or require the federal court to stay or dismiss the federal action in favor of the state-court litigation." 168 And while abstention doctrines invoke a different host of considerations, the underlying principle remains the same: lower federal courts should be wary of interfering in state court proceedings if another way to resolve the case exists. ${ }^{169} \mathrm{Here}$, that alternative means is the affirmative defense of preclusion in state court with review from the state court's appellate system and, if necessary, the Supreme Court. ${ }^{170}$

165 But the court declined to adopt the Seventh Circuit's position that enjoining a state court proceeding under these circumstances constitutes an abuse of discretion. $I d$. at $1191 \mathrm{n} .2$.

166 Id. at 1190-91.

167 Burford v. Sun Oil Co., 319 U.S. 315 (1943).

168 Exxon Mobil Corp. v. Saudi Basic Indus. Corp., 544 U.S. 280, 292 (2005) (citing Colo. River Water Conserv. Dist. v. U.S., 424 U.S. 800 (1976)); see Younger v. Harris, 401 U.S. 37 (1971); Burford v. Sun Oil Co., 319 U.S. 315 (1943).

169 Cf. R.R. Comm'n of Tex. v. Pullman Co., 312 U.S. 496, 501 (1941)

170 See Atl. Coast Line R.R. Co. v. Bhd. of Locomotive Eng'rs, 398 U.S. 281, 297 (1970). 
3. More than Preclusion: It Should Be Rare

At the end of this section, the reader will likely think, "It seems like your approach would make such injunctions really rare." Correct. If that's not your impression, you'll need to read again.

The best place to illustrate how courts should apply the relitigation exception in this context is the Seventh Circuit's decision in Ramsden $v$. AgriBank. ${ }^{171}$ The Ramsdens brought an action in Wisconsin state court against AgriBank and one of its employees for allegedly tortious conduct in the sale of property. ${ }^{172}$ The case against AgriBank eventually found itself in federal court, which granted AgriBank's motion for summary judgment based on unreliable proposed expert testimony. ${ }^{173}$ As a result, the individual employee moved for summary judgment in the state action, arguing issue preclusion based on the federal summary judgment. ${ }^{174}$ Concluding that Wisconsin evidentiary law was less stringent than the federal Daubert standard, the state court denied the employee's motion. ${ }^{175}$ AgriBank's counsel then ran to federal court and successfully obtained an injunction against the state court and the Ramsdens to prevent further prosecution of their claims. ${ }^{176}$

On appeal, the Seventh Circuit recognized that, under Wisconsin law, the state court's denial of summary judgment based on the employee's preclusion defense was not final because it did not dispose of the "entire matter in litigation as to one or more of the parties." 177 But although the court acknowledged that the district court was not statutorily barred from issuing the injunction, it suggested that considerations of comity and federalism should caution against the exercise of that authority:

We believe that a rule that restricts a federal court's discretion to enjoin state court proceedings once the state court expressly and unambiguously decides a res judicata defense, whether or not there has been a final judgment on the entire claim in state court, best reconciles the conflicting concerns identified in Parsons Steel .... Once a state court considers a res judicata defense and rules that a prior federal judgment does not actually

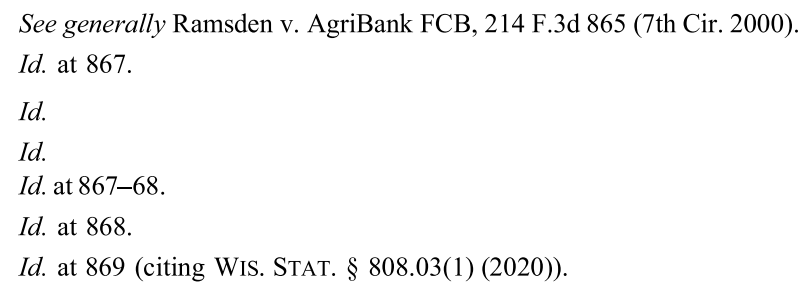


bar a claim, the affront of federal court intervention stripping the state court of power to continue is greatly magnified. ${ }^{178}$

The court qualified this by saying that, in extraordinary circumstances, preventing possible relitigation may outweigh the heightened comity concerns associated with enjoining a state court after its denial of a preclusion defense. ${ }^{179}$ Finding no extraordinary circumstances, the Seventh Circuit explained that treating an injunction under these facts as an abuse of discretion was the only "way to prevent the relitigation exception of the AntiInjunction Act from simply being turned into a vehicle for seeking appellate review of a state court decision in federal court." 180

Following a state court's unambiguous preclusion denial, only a narrow set of circumstances can overcome the principles of comity and equity that already warn against an injunction. The following two sections explain this concept at greater length.

\section{a. Express and Unambiguous Denial}

By requiring that the state court expressly and unambiguously deny the preclusion defense, the federal court yields only to rulings that are sufficiently considered and cautionary. For even absent a final judgment, that a state court's final ruling rejecting preclusion is express and unambiguous implies that the state court will likely not reconsider the issue. For all practical purposes, it becomes a final decision in the eyes of the state court. Although it has since taken a 180-degree turn from this view, the Fifth Circuit explained in Texas Employers Insurance Association v. Jackson ${ }^{181}$ that Parsons Steel does not require a "truly final judgment" in state court for its order denying a preclusion defense to be entitled to Full Faith and Credit. ${ }^{182}$ Rather, the state court's judicial order must simply be final in the sense that it is "beyond recall by the court issuing it." ${ }^{183}$ In other words, the denial of a preclusion defense may be issue preclusive and prevent an injunctive plaintiff from later seeking a federal injunction under the relitigation exception. ${ }^{184}$

178 Id. at $870-71$.

179 Id. at 871

180 Id. at 872 (citing Atl. Coast Line R.R. Co. v. Bhd. of Locomotive Eng'rs, 398 U.S. 281, 293 (1970)).

181 See generally Tex. Emp'rs Ins. Ass'n v. Jackson, 820 F.2d 1406 (5th Cir. 1987).

182 Id. at 1421 ("Parsons Steel speaks in terms of "issues" being finally decided.").

183 Id. (citing RESTATEMENT (SECOND) OF JUDGMENTS $\S 13$, cmt. g (1982) ("Thus, if the state court's ruling was a "final" one, we ourselves our bound by that determination.")).

184 See Twin City Pipe Trades v. Wenner Quality Servs., Inc., 869 F.3d 672, 677 (8th Cir. 2017); Bell v. Taylor, 827 F.3d 699, 707-08 (7th Cir. 2016). 
Contrast that with the District of Columbia District Court's decision in Kaempfer v. Brown. ${ }^{185}$ There, the district court enjoined several defendants from pursuing a tort claim in the District of Columbia Superior Court (i.e., the "state" court). ${ }^{186}$ The superior court had previously denied the injunctive plaintiff's motions to dismiss based on preclusion and other grounds, but its decision was reflected in two one-page orders summarily denying the motions without an explanation behind its grounds or reasons. ${ }^{187}$ Unable to conclude "with the slightest degree of confidence that the Superior Court ha[d] decided the issue of preclusion" in the first place, the district court correctly interpreted Parsons Steel to mean that only a state court's express rejection of a preclusion claim can bind federal courts. ${ }^{188}$

By the same token, a state court may defer a final ruling on the preclusion issue because it remains premature to decide. For example, in Amalgamated Sugar v. NL Industries, ${ }^{189}$ the Second Circuit reviewed the propriety of a federal injunction against state court proceedings when the state court "had not yet ruled on the merits of the res judicata defense raised by [the injunctive plaintiff], but had indicated that it would consider the merits of the res judicata defense only in the context of a full trial on the merits . . . "190 In such a case, although the state court has undeniably considered the issue and not declared the action barred based on preclusion, it cannot be said that the state court has expressly or unambiguously rejected the preclusion defense.

The point is not that a party loses its chance at a federal injunction the moment it chooses state court instead. But to refer back to our introduction's parental squabble, once mom hears it and clearly answers against kidmarital bliss requires more than dad noting that mom issued no reasoned opinion and could technically change her mind.

185 See generally Kaempfer v. Brown, 684 F. Supp. 319 (D.D.C. 1988), aff'd, 872 F.2d 496 (D.C. Cir. 1989).

186 Id. at $320-21,324$.

187 Id. at 322-23. This is not to say that a state court must provide a rationale behind its ruling, but it should at a minimum reflect that the preclusion defense was considered and expressly denied.

188 Id. at 323. But see In re Nat'l Student Marketing Litig., 655 F. Supp. 659, 663-64 (D.D.C. 1987) ("[A] requirement [of showing need for equitable relief] would effectively interpret the relitigation exception into a nullity. Parties can always raise res judicata as a defense to a repetitive lawsuit if compelled to defend this second lawsuit.").

189 Amalgamated Sugar Co. v. NL Indust. Inc., 825 F.2d 634 (2d Cir. 1987).

$190 \quad$ Id. at 642. 


\section{b. Balancing Comity and Relitigation}

Although one could read many lower-court opinions as taking a cavalier attitude towards comity, a better explanation might exist. Complexity impedes comity here. Busy judges and litigants without one hundred hours to dedicate to an article could, perhaps, be forgiven for not being crisp with reasoning about the respect to be given to a preclusion ruling when the preclusion ruling is not preclusive as to a federal injunction based on preclusion. ${ }^{191}$

Take American Town Center v. Hall 83 Associates, ${ }^{192}$ where the Sixth Circuit dropped its entire Parsons Steel analysis at the end of the opinion in a brief footnote. ${ }^{193}$ A federal injunction may be proper even after a state court's denial of preclusion under narrow circumstances, but it won't be simply because the state court's decision is not a final judgment or because the injunctive plaintiff proves the elements of claim or issue preclusion. The ability of a federal district court to enjoin the proceedings of an entirely separate and independent judicial system is a remarkably powerful tool—one that should be exercised sparingly once the state court has heard and rejected the same argument. ${ }^{194}$

On the other hand, the Ramsden court properly balanced the interests of comity with the injunctive plaintiff's interest against possibly relitigating a previously adjudicated claim to determine if any circumstances would warrant an injunction. ${ }^{195}$ Ultimately, the injunctive plaintiff in that case put on no evidence of any extraordinary circumstances, such as harassing or vexatious litigation on behalf of the state court plaintiffs. ${ }^{196}$ Consistent with the Anti-Injunction Act's purpose, the Seventh Circuit treated the relitigation exception narrowly, even more so following a state court's unambiguous denial of the preclusion issue.

191 And after re-reading this sentence several times, understandably so.

192 Am. Town Ctr. v. Hall 83 Assoc., 912 F.2d 104 (6th Cir. 1990).

193 Id. at $112 \mathrm{n} .1$. The Sixth Circuit distinguished Parsons Steel because "the Michigan state court's denial of summary judgment was not a final decision of that court" as it was "subject to revision before entry of judgment adjudicating all the claims." Id. (citing Mich. Ct. R. 2.604(B)). The court, perhaps mistakenly, referred to the state court's decision as a "judgment," but it was simply the denial of a party's motion for summary judgment. The federal district court enjoined the state court's proceedings before the latter had entered a final judgment on the merits. See id. at 107 . However, absent from this footnote was any mention of comity, federalism, or possible friction with state courts by issuing the injunction.

194 See England v. Louisiana St. Bd. of Med. Exam'rs., 375 U.S. 411 (1964) (Even in a situation involving Pullman abstention where a party is forced into state court to present a state argument-if the party voluntarily presents the federal matter to the state court, comity (and probably preclusion) prevents the federal court from revisiting the issue that was, but didn't have to be, presented).

195 Ramsden v. AgriBank FCB, 214 F.3d 865, 872 (7th Cir. 2000).

196 Id. at 872. 
After all, the Supreme Court made it clear that the relitigation exception is "strict and narrow" 197 because no court usually "get[s] to dictate to other courts the preclusion consequences of its own judgment." 198 For this reason, the Court-rejecting the view that the Act represents a "flexible doctrine of comity"199_ has limited injunctions under the relitigation exception "only if preclusion is clear beyond peradventure": ${ }^{200}$

Any doubts as to the propriety of a federal injunction against state court proceedings should be resolved in favor of permitting the state courts to proceed in an orderly fashion to finally determine the controversy. The explicit wording of [the Anti-Injunction Act] itself implies as much, and the fundamental principle of a dual system of courts leads inevitably to that conclusion. ${ }^{201}$

And while circuit courts that typically affirm these injunctions may not openly admit to having any doubts, many of those cases involve considerable disagreement with the state court over whether the federal judgment truly barred the state court proceedings because of complex issues surrounding privity and waiver of claims. ${ }^{202}$ Even if these federal courts are adamantly confident about their position on the preclusion issue, that the issue is hotly contested is undeniable; and "close cases have easy answers: [t]he federal court should not issue an injunction, and the state court should decide the preclusion question." 203

This Article's solution avoids this muddle altogether by allowing the state court proceedings to continue and trusting that, if the subsequent claims or issues are barred, either that state's appellate courts or the Supreme Court can correct the state trial court's erroneous resolution of the preclusion defense. The judgment-issuing district courts may disagree on the preclusion issue, but it's no longer their call to make.

197 Smith v. Bayer Corp., 564 U.S. 299, 306-07 (2011) (quoting Chick Kam Choo v. Exxon Corp., 486 U.S. 140, 148 (1988)).

198 Id. (quoting 18 Charles Alan Wright ET AL., Federal Practice AND Procedure $§ 4405$ (3d ed. 2020) Westlaw (database updated Oct. 20)).

199 Mitchum v. Foster, 407 U.S. 225, 228-29 (1972).

200 Smith, 564 U.S. at 307.

201 Atl. Coast Line R.R. v. Bhd. of Locomotive Eng'rs, 398 U.S. 281, 297 (1970).

202 See, e.g., First Ala. Bank v. Parsons Steel, Inc., 825 F.3d 1475, 1486 (11th Cir. 1987); Vines v. Univ. of La. at Monroe, 398 F.3d 700, 706-07 (5th Cir. 2005); Bryan v. BellSouth Commc'ns, Inc., 492 F.3d 231, 237-39 (4th Cir. 2007)

203 Smith, 564 U.S. at 318. 


\section{Practical Considerations of Comity}

It would be unfair to attribute all the fault to Parsons Steel. Then-Dean Diane Wood said it best when she explained that the Anti-Injunction Act's underlying policy contains "two mutually inconsistent imperatives" that both demand respect of state sovereignty but instruct federal courts to carry out "superior" federal interests. ${ }^{204}$ And taking a step back, it may appear that an injunction under these circumstances is not a huge concern because the circumstances themselves do not come about often. The underlying issue, however, becomes the potentially alarming degree to which circuit courts slowly chip away at the relevant legal principles and broaden a district court's equitable powers over state court proceedings.

The absence of uniform directives to district courts regarding the limits of their discretion when issuing injunctions against state court proceedings will inevitably lead to more uncertainty and expense in parallel litigation, which is already costly by nature. Until the Supreme Court finally settles the circuit split, a narrow interpretation of the relitigation exception in this context is less dangerous than the alternative approach, which permits district courts to have the final say about the preclusive effect of their own judgments without seriously considering the possible friction it may cause with state courts. Only the solution this Article proposes prevents district courts from broadening their injunctive power over state courts and reflects the division of this country's dual judicial system. At least two practical reasons justify this conclusion.

First, issuing a federal injunction against a state court that has rejected a preclusion defense permits the district court to act as an appellate court and review decisions of an independent judicial system. Whether the district court justifies its decision exclusively under the relitigation exception or not, the effect is to essentially vacate and reverse the state court's ruling. ${ }^{205}$ And like the Court in Parsons Steel implicitly proscribed, it "empowers a federal court to be the final adjudicator as to the res judicata effects of its prior judgments on a subsequent state action." 206 The result is a system of parallel proceedings allowing a party that prevails in federal court but loses on the preclusion issue in state court to circumvent the latter's appellate system and seek relief through the district court instead. This de facto appellate system flies in the

204 Wood, supra note 78, at 320.

205 See, e.g., Sandpiper Vill. Condo. Ass'n v. La.-Pac. Corp., 428 F.3d 831, 851 (9th Cir. 2005) ("That ruling was tantamount to a judgment reversing a state court on a matter of state law.")

206 Parsons Steel, Inc. v. First Ala. Bank, 474 U.S. 518, 522 (1986) (internal quotations omitted). 
face of constitutional limitations barring federal district courts from "engaging in appellate review of state-court determinations."207

Second, a broad interpretation would cause unnecessary friction between federal and state courts. As the Supreme Court has emphasized in many of its recent landmark decisions, such as Chick Kam Choo ${ }^{208}$ and Bayer Corp. ${ }^{209}$ the Anti-Injunction Act was at least partially a response to potential friction between federal and state courts. ${ }^{210}$ Circuit courts that typically permit relitigation exception injunctions might argue that their only concern is the protection or effectuation of their judgments, not overturning state court rulings. Whether the district court says it or not, however, its decision to enjoin the state court after it rejects the preclusion defense is-in all but name- a reversal of the state court's ruling. ${ }^{211}$ Such a direct confrontation lies at the heart of the unnecessary friction that the Anti-Injunction Act was designed to avoid.

A state court's interlocutory ruling on a preclusion defense may be incorrect, even blatantly so, but as in Atlantic Coast Line, the injunctive plaintiff must pursue relief through the state court system with ultimate review by the Supreme Court. ${ }^{212}$ Federal district courts cannot and should not shorten this process by stepping in and overturning the state court's resolution of the preclusion issue. State courts didn't develop their preclusion principles in order to protect their interlocutory rulings against federal injunctions. A broad interpretation of the relitigation exception punishes state courts for this and accords their interlocutory rulings virtually no deference without regard to what stage the state proceedings may have reached. ${ }^{213}$

\section{CONCLUSION}

Complexity seems to have impeded comity in several ways. First, the mere procedural complexity is a level beyond the preclusive effect of a preclusion ruling. Second, the Anti-Injunction Act and its exceptions have a

207 Pennzoil Co. v. Texaco, Inc., 481 U.S. 1, 21 (Brennan, J., concurring).

208 Chick Kam Choo v. Exxon Corp., 486 U.S. 140, 146 (1988).

209 Smith v. Bayer Corp., 564 U.S. 299, 306-07 (2011).

210 See Vendo Co. v. Lektro-Vend Corp., 433 U.S. 623, 630-31 (1977) (plurality opinion).

211 See Sandpiper Vill. Condo Ass'n v. La.-Pac. Corp., 428 F.3d 831, 851 (9th Cir. 2005).

212 See Atl. Coast Line R.R. v. Bhd. of Locomotive Eng'rs, 398 U.S. 281, 287 (1970).

213 E.g., Vines v. Univ. of La. at Monroe, 398 F.3d 700, 712-13 (5th Cir. 2005) (enjoining state court proceedings after the state appellate court definitively ruled that federal judgment did not bar the subsequent state proceeding). 
contentious history, ${ }^{214}$ and they are certainly no strangers to criticism. ${ }^{215}$ Indeed, most agree that the relitigation exception itself seems to contradict fundamental principles of judicial federalism and comity. ${ }^{216}$ Third, other interpretative issues involving the relitigation exception make researching the area difficult. ${ }^{217}$

So, in this area of extreme density, it's perhaps understandable ${ }^{218}$ for someone to conclude that the inquiry starts and ends with preclusion. But it doesn't because the context we have been writing about involves a federal court enjoining a state court proceeding based on a legal issue-preclusionthat the state court has already held is not preclusive. That sequence triggers all the concerns highlighted throughout this Article.

To be sure, this Article in no way argues that preclusion and the finality of federal judgments should take a back seat. But the point is that they should not take up the entire front seat, either. The solution proposed here does not tie the hands of federal courts any more than Parsons Steel already does; it simply acknowledges that a state court's denial of a preclusion defense magnifies the concerns of comity and federalism that precipitated the AntiInjunction Act in the first place. If the state court expressly and unambiguously has ruled, then equity, comity, and far more than just the Anti-Injunction Act counsel that the injunction should be issued almost never.

214 See supra text and table accompanying note 28.

215 Wood, supra note 78, at 320 ("The Anti-Injunction Act is badly in need of attention."); David P. Currie, The Federal Courts and the American Law Institute, Part II, 36 U. CHI. L. REV. 268, 322 (1969).

216 See Redish, supra note 7, at 725

217 Chick Kam Choo v. Exxon Corp., 486 U.S. 140, 140 (1988); see supra Part VI.B. (adequate remedies discussion)

218 But not on Ryan's exam. 